\title{
Enzyme Inhibitory and Antioxidant Activities of Different Extracts from Ruscus aculeatus $\mathrm{L}$.
}

\author{
Turgut Taşkın ${ }^{1 *}$, Ece Güler², Talip Şahin ${ }^{3}$, Gizem Bulut ${ }^{4}$ \\ 1 Marmara University, Faculty of Pharmacy, Pharmacognosy, Istanbul, Turkey. \\ 2 Marmara University, Faculty of Pharmacy, Department of Pharmacology, Istanbul, Turkey. \\ 3 Marmara University, Faculty of Pharmacy, Department of Biochemistry, Istanbul, Turkey. \\ 4 Marmara University, Faculty of Pharmacy, Department of Pharmaceutical Botany, Istanbul, Turkey
}

\begin{abstract}
The goal of this work was to evaluate in vitro antioxidant, anti-urease and anticholinesterase activities of Ruscus aculeatus L. using a variety of extracts. Antioxidant activities of different extracts from plant were evaluated using DPPH, FRAP, ABTS/ TEAC and CUPRAC methods. In addition, the anti-urease and anticholinesterase activities of the different extracts were compared by Indophenol and Ellman tests, respectively. In the present study, Soxhlet chloroform extract showed stronger antioxidant (DPPH, FRAP, CUPRAC) and anticholinesterase activity than other extracts. It was also found that the maceration ethanol extract showed the most potent anti-urease activity. The Soxhlet chloroform and maceration ethanol extracts from this species may be a natural resource candidate for the pharmaceutical and food industry due to the pharmacological effects (antioxidant, anticholinesterase and anti-urease effect).
\end{abstract}

Key words: $R$. aculeatus; antioxidant, anti-urease, anticholinesterase

\section{INTRODUCTION}

In the biological system, reactive oxygen species (ROS) and nitrogen types (RNS) can damage DNA and lead to oxidation of lipids and proteins in cells. Normally, the antioxidant system occurring in the human body can clear these radicals, but exposure to smoking, alcohol, radiation or environmental toxins induces excess ROS and RNS production. Increased intake of exogenous antioxidants reduces the effects caused by these radicals. Natural antioxidants are

\footnotetext{
${ }^{*}$ Corresponding author: Olajire Adegoke, e-mail: ao.adegoke@mail.ui.edu.ng Turgut Taşkın ORCID Number: 0000-0001-8475-6478 Ece Güler ORCID Number: 0000-0001-8519-2125

Talip Şahin ORCID Number: 0000-0002-0911-4851

Gizem Bulut ORCID Number: 0000-0002-6891-4277

(Received 21 January 2020, accepted 25 February 2020)
} 
commonly found in food and medicinal plants. These natural antioxidants have a wide range of biological effects, including anti-inflammatory, anti-aging, antiatherosclerosis and anticancer ${ }^{1-4}$.

Alzheimer's disease (AD) is one of the most common neurodegenerative diseases. It is related with memory, learning abilities and life quality of individuals. This disease is expressed by the presence of $\beta$-amyloid plaque, intracellular neurofibrillary tangles (NFTs), synaptic deterioration, and neuronal death ${ }^{5,6}$. To treat of $\mathrm{AD}$ is is used rivastigmine, galantamine, donepezil, memantine, memantine combined with donepezil, tacrine and memantine but none of the pharmacologic treatments available today for Alzheimer's dementia slow or stop the damage and destruction of neurons that cause Alzheimer's symptoms and make the disease fatal 7 .

Helicobacter pylori (HP) usually colonizes in the surface of human gastric mucosa and duodenal bulb. After that releases urease that converts urea into ammonia. This enzyme produces an alkaline environment that makes it suitable for bacterial growth and the manifestation of the disease. H.pylori causes chronic gastritis, gastric carcinoma, duodenal ulcer in more than $50 \%$ of people. At the same time in more than \%80 of people with $H$.pylori are asymptomatic. Therefore it is the most critical widespread infection in the world and plays a big role in maintaining stomach ecology ${ }^{8}$. It has been tested that a urease-negative mutant does not cause gastritis due to difficulties in colonization, therefore, specific inhibition of urease activity has been proposed as a successful strategy to eliminate the organism in the body. To treat of $H$. pylori it is used triple therapy, which includes a proton pump inhibitor and any of the two antibiotics such as amoxicillin (AMX), clarithromycin (CLA), metronidazole (MNZ) and tetracycline (TET) ${ }^{9}$.

Medicinal herbs have historically been a valuable source of therapeutic agents, and most of the drugs used today are natural products of plant origin or derivatives thereof. According to the World Health Organization (WHO), over 80\% of the world population uses traditional medicine for primary health care. The number of studies on these has increased in recent years as natural products such as plant extracts, either as pure compounds or as standardized extracts offer unlimited opportunities for new drug discoveries ${ }^{10-13}$.

Ruscus aculeatus L. (butcher's broom) is belong to the Asparagaceae family and it grows wildly in the forests in Mediterranean Europe and Africa. It has tough, green, erect, striated stems and very rigid leaves. The small greenish-white flowers grow from the center of the leaves and bloom in the early spring. The thick root, typically collected in autumn, is used medicinally. $R$. aculeatus includes 
steroidal saponins, ruscogenin, neoroscogenin, essential oils, flavonoids, resin and minerals. This plant is used for treatment of venous insufficiency / varicosities edema such as circulatory disorders, edema, thrombophlebits, swelling and also used as diuretic. Also it is used in premenstrual syndrome, hemorrhoids, diabetic retinopathy, skin disease, against inflammation and arthritis ${ }^{14-16}$.

The best of our knowledge, there are no reports on the effect of extraction methods on the biological activity (antioxidant, anti- urease, and anticholinesterase) of this plant. For this reason, the aim of this work was to evaluate in vitro antioxidant, anti-urease and anticholinesterase activities of $R$. aculeatus using a variety of extracts.

\section{METHODOLOGY}

\section{Identification of plant material}

Ruscus aculeatus L. was taxonomically identified by Dr. Gizem Bulut. The voucher specimens, representative samples of the plant material, were archived in the herbarium of the Faculty of Pharmacy, Marmara University and documented with the herbarium number of MARE:19140.

\section{Preparation of Ruscus aculeatus extracts}

Aerial parts of Ruscus aculeatus were dried at $25^{\circ} \mathrm{C}$ in the shade. Dried parts of the plant were treated with a mechanical grinder (Renas, RBT1250) for fine powder and proper weight. The two extraction methods were performed to gain crude extracts from the aerial parts of the plant. Maceration: Plant powder (20 g) was extracted with the use of petroleum ether, chloroform, and ethanol until colorless. Soxhlet extraction: 20 gram of plant powder was extracted in Soxhlet apparatus with petroleum ether, chloroform and ethanol. The six different extracts from plant were concentrated by rotary vacuum evaporator. All the extracts obtained were stored at $4^{\circ} \mathrm{C}$ for future analysis.

\section{In vitro bioactivity assays}

\section{2,2-diphenyl-1-picryl-hydrazyl (DPPH) radical scavenging assay}

$240 \mu \mathrm{L} \mathrm{0.1} \mathrm{mM} \mathrm{DPPH} \mathrm{solution} \mathrm{was} \mathrm{added} \mathrm{to} 10 \mu \mathrm{L}$ sample of the extracts at different concentrations (0.5-5 mg/mL). Prepared mixture was stirred for $1 \mathrm{~min}$. and placed at $25^{\circ} \mathrm{C}$ for $30 \mathrm{~min}$. The mixture absorbance was determined against the reference at $517 \mathrm{~nm}$. Control sample was carried out under the same conditions using $10 \mu \mathrm{L}$ of methanol instead of experimental and standard materials and the control sample was daily measured. The investigation was performed three times and the averages of the data and standard deviation were calculated. The data gained from the investigation was given as $\mathrm{IC}_{50}=\mathrm{mg} / \mathrm{mL}^{17}$. 


\section{2,2'-azino-bis(3-ethylbenzothiazoline-6-sulfonate) radical cation}

\section{(ABTS $^{+}$) scavenging assay}

$50 \mu \mathrm{L}$ of extracts prepared at different concentrations (1-5 mg/mL), $50 \mu \mathrm{L}$ of ABTS $\cdot{ }^{+}$working solution and $150 \mu \mathrm{L}$ distilled water were added on the prepared extracts. The mixture absorbance was determined against the reference at 734 $\mathrm{nm}$ for $6 \mathrm{~min}$. Control sample was prepared under the same conditions with the use of $50 \mu \mathrm{L}$ distilled water instead of experimental and standard materials. The control sample was daily measured. ABTS radical scavengimg determination was applied to trolox solutions prepared at different concentration (0.2-1 mM). The results from this study were given as $\mathrm{mM}$ trolox/g extract ${ }^{18}$.

\section{Ferric reducing/antioxidant power (FRAP) assay}

The method of Benzie and Strain (1996) was applied to the extracts in order to estimate the ferric reducing ability. The FRAP reagent $[25 \mathrm{~mL} 300 \mathrm{mM}$ acetate buffer (pH 3.6), $2.5 \mathrm{~mL}$ of TPTZ solution and $2.5 \mathrm{~mL} 20 \mathrm{mM} \mathrm{FeCl}_{3} \cdot 6 \mathrm{H}_{2} \mathrm{O}$ ] was kept at $37^{\circ} \mathrm{C}$ for $30 \mathrm{~min} .190 \mu \mathrm{L}$ FRAP reagent was mixed with $10 \mu \mathrm{L}$ extract and the mixture absorbance was determined at $593 \mathrm{~nm}$ after $4 \mathrm{~min}$. FRAP values of the extracts were given as $\mathrm{mM} \mathrm{Fe}{ }^{2+} / \mathrm{mg}$ extract ${ }^{19}$.

\section{Cupric ion reducing/antioxidant power (CUPRAC) assay}

$60 \mu \mathrm{L} \mathrm{Cu}(\mathrm{II}) \mathrm{x}_{2} \mathrm{H}_{2} \mathrm{O}, 60 \mu \mathrm{L}$ neocuproine and $60 \mu \mathrm{L}, \mathrm{NH}_{4} \mathrm{Ac}(1 \mathrm{M})$ were mixed. Then $60 \mu \mathrm{L}$ of the extract and $10 \mu \mathrm{L}$ of ethanol were added to the mixture. After the duration time of $60 \mathrm{~min}$, the mixture absorbance was spectrophotometrically measured at $450 \mathrm{~nm}$. CUPRAC values of the extracts were given as $\mathrm{mM}$ trolox/mg extract ${ }^{20}$.

\section{Anti-urease activity assay}

Stock solutions were prepared from different extracts obtained from the plant and these solutions were diluted to prepare working solutions. Working solution $(100 \mu \mathrm{L})$ was taken and urease $(500 \mu \mathrm{L})$ was added on it. The mixture was incubated at $37^{\circ} \mathrm{C}$ for $30 \mathrm{~min}$. Then, $1100 \mu \mathrm{L}$ of urea was added on this mixture and kept in the incubator at $37^{\circ} \mathrm{C}$ for $30 \mathrm{~min}$. $\mathrm{R} 1$ (1\% phenol, $0.005 \%$ sodium nitroprusside) and $\mathrm{R} 2$ (0.5\% $\mathrm{NaOH}, 0.1 \%$ sodium hypochlorite) reagents were added to the mixture, respectively. After the incubation period at $37^{\circ} \mathrm{C}$ for $2 \mathrm{~h}$, the absorbance of samples was measured at $635 \mathrm{~nm}^{21}$.

The \% inhibition of urease was calculated by the formula:

$\%$ enzyme inhibition $\left.=\left[\left(\mathrm{A}_{\mathrm{o}}-\mathrm{A}_{1}\right) / \mathrm{A}_{\mathrm{o}}\right] \times 100\right]$

$\mathrm{A}_{\mathrm{o}}$ : The absorbance of the control solution

$\mathrm{A}_{1}$ : Absorbance of plant extracts and standard solutions. 


\section{Anticholinesterase activity assay}

Inhibition activities of acetylcholinesterase (AchE) were measured using microplate reader. Acetylcholinesterase as enzyme source derived from electric fish, acetyl thiokolin iodide was used as substrate. Yellow-colored 5,5-dithiobis- (2-nitrobenzoic acid) (DTNB) was used for the measurement of activity. As a control, ethanol and galantamine, the alkaloid type drug isolated from the galanthus plant, were used as controls.

\section{AChE \% Inhibition Test}

AChE $(20 \mu \mathrm{L})$ and different concentrations of extracts $(20 \mu \mathrm{L})$ were added to phosphate buffer solution (pH 8.2 $0.1 \mathrm{M}, 40 \mu \mathrm{L})$. This mixture was incubated at $25^{\circ} \mathrm{C}$ for $10 \mathrm{~min}$. After incubation, DTNB $(100 \mu \mathrm{L})$ and AcI $(20 \mu \mathrm{L})$ as substrate were added on the mixture. The same procedure was applied to the galantamine used as standard. 5-thio-2-nitrobenzoic acid was spectrophotometrically measured at $412 \mathrm{~nm}$. Anticholinesterase activity of the extracts was calculated using the following equation as\% inhibition relative to control ${ }^{22}$.

$\% \mathrm{I}=($ Acontrol - Asample/Acontrol) $\times 100$

\section{Statistical analysis}

All the experiments were done in triplicates. The results of the antioxidant, anticholinesterase and anti-urease experiments were demonstrated as mean \pm SD. All the data was analysed by the Graphpad Prism 5 program. Statistical differences between the study groups were analysed using two-way analysis of variance (ANOVA) followed by Tukey's Multiple Comparison test and p-values less than 0.05 were considered statistically significant.

\section{RESULTS AND DISCUSSION}

\section{In vitro evaluation of biological activity}

\section{Antioxidant activity of extracts}

The antioxidant activities of plant's different extracts were shown in Table 1. The Soxhlet chloroform $\left(\mathrm{IC}_{50} \mathrm{O} .18 \mathrm{mg} / \mathrm{mL}\right.$ ) extract showed the strongest DPPH free radical scavenging activity. The petroleum ether extracts obtained from Soxhlet and maceration extraction methods showed the lowest DPPH free radical scavenging activity. As shown in Table 1, the radical scavenging DPPH activities of all extracts showed lower than that of ascorbic acid $\left(\mathrm{IC}_{50}: 0.005\right.$ $\mathrm{mg} / \mathrm{mL}$ ) and BHA ( $\mathrm{IC}_{50}: 0.006 \mathrm{mg} / \mathrm{mL}$ ). When the results of all extracts were compared for ABTS radical cation scavenging activity, it found that ethanol extracts obtained from Soxhlet (3.24 mM trolox/g extract) and maceration (3.22 
$\mathrm{mM}$ trolox/g extract) extraction methods exhibited the strongest ABTS radical cation scavenging activity. Soxhlet chloroform (0.37 $\mathrm{mM} \mathrm{Fe} \mathrm{F}^{2+} / \mathrm{mg}$ extract) and maceration chloroform extracts (0.33 $\mathrm{mM} \mathrm{Fe}{ }^{2+} / \mathrm{mg}$ extract) showed stronger ferric reducing activity than other extracts. When the results of all extracts and standard were compared, it found that all extracts exhibited lower ferric reducing activity than BHT.

The chloroform extracts obtained from Soxhlet ( $0.86 \mathrm{mM}$ trolox/mg extract) and maceration (0.50 $\mathrm{mM}$ trolox/mg extract) extraction methods exhibited stronger cupric reducing antioxidant activity than other extracts. When the results of the CUPRAC assay were examined, the all extracts showed lower cupric reducing antioxidant activity than BHA compounds.

The results obtained from this study showed that Soxhlet extraction techniques are the most suitable method to get the most powerful DPPH, ABTS, FRAP and CUPRAC antioxidant activity. It was also found that the most suitable solvent for obtaining high DPPH, FRAP and CUPRAC values was chloroform.

Table 1. Effects of extracting solvents/methods on the antioxidant activity of Ruscus aculeatus extracts

\begin{tabular}{|c|c|c|c|c|c|c|c|c|}
\hline \multirow[b]{2}{*}{ Samples } & \multicolumn{2}{|c|}{$\begin{array}{c}\mathrm{DPPH} \\
\left(\mathrm{IC}_{50}: \mathrm{mg} / \mathrm{mL}\right)\end{array}$} & \multicolumn{2}{|c|}{$\begin{array}{c}\text { ABTS } \\
\text { (mM trolox/g extract) }\end{array}$} & \multicolumn{2}{|c|}{$\begin{array}{c}\text { FRAP assay } \\
\text { (mM Fe } \mathrm{e}^{2+} / \mathrm{mg} \text { extract) }\end{array}$} & \multicolumn{2}{|c|}{$\begin{array}{c}\text { CUPRAC assay } \\
\text { (mM trolox/mg extract) }\end{array}$} \\
\hline & Soxhlet & Maceration & Soxhlet & Maceration & Soxhlet & Maceration & Soxhlet & Maceration \\
\hline $\begin{array}{l}\text { Petroleum } \\
\text { ether }\end{array}$ & $\begin{array}{c}2.32 \pm 0.0 \\
8^{\mathrm{a}}\end{array}$ & $0.83 \pm 0.02^{\mathrm{a}}$ & $\begin{array}{c}1.63 \pm 0.01 \\
a\end{array}$ & $1.56 \pm 0.03^{\mathrm{a}}$ & $\begin{array}{c}0.15 \pm 0.0 \\
01^{\mathrm{a}}\end{array}$ & $0.10 \pm 0.001^{a}$ & $\begin{array}{c}0.35 \pm 0.00 \\
1^{a}\end{array}$ & $0.25 \pm 0.002^{a}$ \\
\hline Chloroform & $\begin{array}{c}0.18 \pm 0.0 \\
01^{b}\end{array}$ & $0.81 \pm 0.02^{b}$ & $\underset{b}{1.92 \pm 0.13}$ & $3.10 \pm 0.02^{b}$ & $\begin{array}{c}0.37 \pm 0.0 \\
02^{b}\end{array}$ & $0.33 \pm 0.002^{b}$ & $\begin{array}{c}0.86 \pm 0.00 \\
2^{b}\end{array}$ & $0.50 \pm 0.005^{b}$ \\
\hline Ethanol & $\begin{array}{c}0.26 \pm 0.0 \\
04^{c}\end{array}$ & $0.79 \pm 0.10^{c}$ & $\underset{\mathrm{c}}{3.24 \pm 0.01}$ & $3.22 \pm 0.01^{c, b}$ & $\begin{array}{c}0.12 \pm 0.0 \\
03^{c, a}\end{array}$ & $\underset{, b}{0.32 \pm 0.004^{c}}$ & $\begin{array}{c}0.11 \pm 0.00 \\
1^{c}\end{array}$ & $0.15 \pm 0.004^{c}$ \\
\hline $\begin{array}{l}\text { Ascorbic } \\
\text { acid }\end{array}$ & $\begin{array}{l}0.005 \\
0.005\end{array}$ & $\begin{array}{l}=0.009^{d} \\
=0.00 g^{d}\end{array}$ & $\begin{array}{r}13.01 \pm 0.01 \\
13.01\end{array}$ & $\pm 0.01^{d}$ & & & & \\
\hline BHT & & & & & $1.1 \pm 0.12^{d}$ & $1.1 \pm 0$ & & \\
\hline BHA & $0.006 \pm 0.00$ & $b^{e} \quad 0.006 \pm 0$ & & & & & $\begin{array}{r}1.6 \\
1.62\end{array}$ & $\begin{array}{l}2 \pm 0.12^{d} \\
\pm 0.12^{d}\end{array}$ \\
\hline
\end{tabular}

Values are mean of triplicate determination $(n=3) \pm$ standard deviation; Means with different superscripts ${ }^{(a-d)}$ are significantly different, $p<0.05$. 


\section{Urease inhibitory activity}

The percentage of inhibition of urease enzyme at $12.5 \mu \mathrm{g} / \mathrm{mL}$ concentration of different extracts was determined by using indophenol method and the results were shown in Table 2. In Soxhlet method, ethanol (29.19 \%) extract showed stronger anti-urease activity than other extracts. In maceration method, ethanol (34.24 \%) extract exhibited the highest anti-urease activity. The petroleum ether obtained from both extraction methods did not show anti-urease activity in this study. Comparing the activity results of all the extracts, it was found that maceration ethanol extract had the strongest anti-urease activity and all extract showed lower activity than thiourea compounds (78.84\%). The results showed that maceration extraction technique is the most suitable method to obtain the strongest anti-urease activity. It was also found that the most suitable solvent for obtaining strong anti-urease activity was ethanol.

Table 2. The urease inhibitory activity of different extracts from Ruscus aculeatus

\begin{tabular}{|l|l|l|}
\hline \multirow{2}{*}{ Samples } & \multicolumn{2}{|l|}{ Urease inhibition $(\%)(\mathbf{1 2 . 5} \boldsymbol{\mu g} / \mathrm{mL})$} \\
\cline { 2 - 3 } & Soxhlet & Maceration \\
\hline Petroleum ether & NA & NA \\
\hline Chloroform & $19.09 \pm 1.2^{\mathrm{a}}$ & $19.09 \pm 1.2^{\mathrm{a}}$ \\
\hline Ethanol & $29.19 \pm 1.8^{\mathrm{b}}$ & $29.19 \pm 1.8^{\mathrm{b}}$ \\
\hline Galantamine & $78.84 \pm 0.9^{\mathrm{c}}$ & $78.84 \pm 0.9^{\mathrm{c}}$ \\
\hline
\end{tabular}

Values are mean of triplicate determination $(n=3) \pm$ standard deviation; Means with different superscripts ${ }^{(a-c)}$ are significantly different, $p<0.05$; NA: not activity

\section{Anticholinesterase activity}

The percentage of inhibition of cholinesterase enzyme at $500 \mu \mathrm{g} / \mathrm{mL}$ concentration of different extracts was determined by using Ellman method and the results were shown in Table 3. In Soxhlet method, chloroform (94.37\%) extract exhibited higher percentage of inhibition of cholinesterase enzyme than other extracts. In maceration method, ethanol (80.87\%) extract showed the strongest anticholinesterase activity. The Soxhlet petroleum ether and maceration petroleum ether extracts did not show cholinesterase inhibitory activity. In the present study, Soxhlet chloroform method/solvent were the most suitable solvent and method to get the strongest anticholinesterase activity. The compounds or extracts having strong antioxidant activity is generally known to have strong anticholinesterase activity. In this study, Soxhlet chloroform extract showing strong antioxidant activity (DPPH, FRAP, CUPRAC) in parallel with the literature also showed strong anticholinesterase activity. 
Table 3. The anticholinesterase activity of different extracts from Ruscus aculeatus

\begin{tabular}{|l|l|l|}
\hline \multirow{2}{*}{ Samples } & $\begin{array}{l}\text { Enzyme inhibition (\%) (500 } \\
\boldsymbol{\mu g} / \mathbf{m L})\end{array}$ & $\begin{array}{l}\text { Enzyme inhibition (\%) } \mathbf{( 5 0 0} \\
\boldsymbol{\mu} / \mathbf{m L})\end{array}$ \\
\cline { 2 - 3 } & Soxhlet & Soxhlet \\
\hline Petroleum ether & NA & NA \\
\hline Chloroform & $94.37 \pm 1.2^{\mathrm{a}}$ & $94.37 \pm 1.2^{\mathrm{a}}$ \\
\hline Ethanol & $84.35 \pm 1.3^{\mathrm{b}}$ & $84.35 \pm 1.3^{\mathrm{b}}$ \\
\hline Galantamine & $96.54 \pm 0.9^{\mathrm{c}, \mathrm{a}}$ & $96.54 \pm 0.9^{\mathrm{c}, \mathrm{a}}$ \\
\hline
\end{tabular}

Values are mean of triplicate determination $(\mathrm{n}=3) \pm$ standard deviation; Means with different superscripts ${ }^{(a-c)}$ are significantly different, $p<0.05$; NA: not activity.

Literature information on the antioxidant activity of aerial parts of $R$. aculeatus are scarce, while there not any anti-urease and anticholinesterase activity for this species. In a study, methanol, ethyl acetate and butanol extracts from the aerial parts of the plant and their antioxidant and antimicrobial activities were examined. According to the obtained data, the fraction ethyl acetate $\left(\mathrm{IC}_{50}: 158\right.$ $\mu \mathrm{g} / \mathrm{mL}$ ) and butanol ( $\mathrm{IC}_{50}: 173 \mu \mathrm{g} / \mathrm{mL}$ ) extracts were found to have the strongest DPPH radical scavenging activity. In addition, it was found that fraction ethyl acetate extract showed stronger antimicrobial activity than other extracts ${ }^{14}$. When we compared the results above with our results, it was found that the Soxhlet chloroform $\left(\mathrm{IC}_{50}: 180 \mu \mathrm{g} / \mathrm{mL}\right.$ ) extract was close to the butanol extract ( $\mathrm{IC}_{50}: 173 \mu \mathrm{g} / \mathrm{mL}$ ), but all extracts obtained from both extraction methods exhibited lower DPPH radical scavenging activity than ethyl acetate and butanol extracts.

In another study, ethanol, acetone and ethyl acetate extracts obtained using Soxhlet method from the aerial parts of the plant and antioxidant activities of these extracts were investigated. In this study, acetone and ethyl acetate extracts showed the best total antioxidant capacity (23.329 $\mu \mathrm{g} \mathrm{AA} \mathrm{g}^{-1}$ ) and the highest DPPH scavenging activity $\left(\mathrm{IC}_{50}=182.54 \mu \mathrm{g} \mathrm{mL}^{-1}\right)$ respectively ${ }^{16}$.

When we compared the results of this study with the results of the literature, it was found that the Soxhlet chloroform $\left(\mathrm{IC}_{50}: 180 \mu \mathrm{g} / \mathrm{mL}\right.$ ) extract showed DPPH radical scavenging activity very close to the ethyl acetate $\left(\mathrm{IC}_{50}=182.54 \mu \mathrm{gL}\right.$ -1 ) extract.

Luis et al. investigated the antioxidant activity of methanol extract obtained using Soxhlet method from the plant's aerial parts and found that this extract showed strong DPPH $\left(\mathrm{IC}_{50} 0.172 \mathrm{mg} / \mathrm{mL}\right.$ ) radical scavenging activity ${ }^{23}$. According to the data obtained in this study, Soxhlet ethanol extract $\left(\mathrm{IC}_{50} 0.26 \mathrm{mg}\right.$ / $\mathrm{mL}$ ) obtained in our study showed lower DPPH radical scavenging activity than the methanol extract $\left(\mathrm{IC}_{50} 0.172 \mathrm{mg} / \mathrm{mL}\right.$ ) in the literature. Moreover, no stud- 
ies on the anti-urease and anticholinesterase activity of the plant were found in the literature review and the anti-urease and anticholinesterase activities of the different extracts from the plant were examined for the first time in this study.

Consequently, according to the results of this study, Soxhlet chloroform extract showed stronger antioxidant (DPPH, FRAP, CUPRAC) and anticholinesterase activity than other extracts. It was also found that the maceration ethanol extract showed the most potent anti-urease activity. Therefore, Soxhlet chloroform and maceration ethanol extracts from this species may be a natural resource candidate for the pharmaceutical and food industry due to the pharmacological effects (antioxidant, anticholinesterase and anti-urease effect).

\section{Conflict of interest}

The authors declare that there is no conflict of interest regarding the publication and dissemination of the information provided here in.

\section{Funding sources}

The authors declare that there is no funding sources of interest regarding the publication. 


\section{REFERENCES}

1. Xu, D.P.; Li, Y.; Meng, X.; Zhou, T.; Zhou, Y.; Zheng, J.; Zhang, J.J.; Li1, H.B. Natural antioxidants in foods and medicinal plants: extraction, assessment and resources. Int J Mol Sci 2017. 18(1), 96-99.

2. Peng, C.; Wang, X.; Chen, J.; Jiao, R.; Wang, L.; Li, Y.M.; Zuo, Y.; Liu, Y.; Lei, L.; Ma, K.Y.; Huang, Y.; Chen, Z.Y. Biology of ageing and role of dietary antioxidants. BioMed Res Int 2014. 2014, 1-13.

3. Li, S.; Tan, H.Y.; Wang, N.; Zhang, Z.J.; Lao, L.; Wong, C.W.; Feng, Y. The role of oxidative stress and antioxidants in liver diseases. Int J Mol Sci 2015. 16(11), 26087-26124.

4. Wang, F.; Li, Y.; Zhang, Y.J.; Zhou, Y.; Li, S.; Li, H.B. Natural products for the prevention and treatment of hangover and alcohol use disorder. Molecules. 2016. 21(1), 1-21.

5. Bostancıklığlu, M. An update on the interactions between Alzheimer's disease, autophagy and inflammation. Gene 2019. 705, 157-166.

6. Ulep, M.G.; Saraon, S.K.; McLea, S. Alzheimer Disease. J Nurse Pract 2018. 14, 129-135.

7. Colović, M.B.; Krstić, D.Z; Lazarević-Pašti, T.D.; Bondžić, A.M.; Vasić, V.M. Acetylcholinesterase inhibitors: pharmacology and toxicology. Curr Neuropharmacol 2013. 11, 315335 .

8. Yao, Y.; Shen, Y.; Zhu, L.; Ni, Y.; Wang, H.; Shao, S. Preliminary study and bioinformatics analysis on the potential role of CagQ in type IV secretion system of H.pylori. Microb Pathog 2018. 116, 1-7.

9. Amin, M.; Anwar, F.; Naz, F.; Mehmood, T.; Saari, N. Anti-Helicobacter pylori and urease inhibition activities of some traditional medicinal plants. Molecules 2013. 18, 2-8

10. Atanasov, A.G.; Waltenberger, B.; Pferschy-Wenzig, E.M.; Linder, T.; Wawrosch, C.; Uhrin, P.; Temm, V.; Wang, L.; Schwaiger, S.; et al. Discovery and resupply of pharmacologically active plant-derived natural products: A review. Biotechnol Adv 2015. 33(8),1582-1614.

11. Kinghorn, A.D.; Pan, L.; Fletcher, J.N.; Chai, H. The relevance of higher plants in lead compound discovery programs. J Nat Prod 2011.74,1539-1555.

12. Sasidharan, S.; Chen, Y.; Saravanan, D.; Sundram, K.M.; Latha, L.Y. Extraction, isolation and characterization of bioactive compounds from plants' extracts. Afr $J$ Tradit Complement Altern Med. 2011. 8(1), 1-10.

13. Duraipandiyan, V.; Ayyanar, M.; Ignacimuthu, S. Antimicrobial activity of some ethnomedicinal plants used by Paliyar tribe from Tamil Nadu, India. BMC Complementary Altern Med. 2006. 6, 35-41.

14. Hadžifejzović, N.; Kukić-Marković, J; Petrović, S.; Soković, M.; Glamočlija, J.; Stojković, D.; Nahrstedt, A. Bioactivity of the extracts and compounds of Ruscus aculeatus L. and Ruscus hypoglossum L. Ind Crop Prod 2013. 49, 407-411.

15. Maswadeh, H.M.; Semreen, M.H.; Naddaf, A.R. Anti-inflammatory activity of Achillea and Ruscus topical gel on carrageenan-induced paw edema in rats. Acta Pol Pharm 2006. 63, 277-80.

16. Jakovljevic, V.D.; Milicevic, J.M.; Djelic, G.T.; Vrvic, M.M. Antioxidant activity of Ruscus species from Serbia; Potential new sources of natural antioxidants. Hem ind 2016. 70, 99-106.

17. Wei, F.C.; Jinglou, C.; Yongfang, C.; Liming, P. L. Antioxidant, free radical scavenging, anti-inflammatoryand hepatoprotective potential of the extract from Parathelypteris nipponica (Franch.etSav.) Ching. $J$ Ethnopharmacol 2010. 130, 521-528. 
18. Re, R.N.; Pellegrını, A.; Proteggente, A.; Pannala, M.; Yang, C.R.Antioxidant activity applying an improved ABTS radical cation decolorization assay. Free Radical Bio Med 1999. 26, 1231-1237.

19. Benzie, I.F.; Strain, J.J. The ferric reducing ability of plasma (FRAP) as a measure of "antioxidant power": the FRAP assay. Anal Biochem 1996. 239, 70-76.

20. Apak, R.; Güclü, K.; Ozyurek, M.; Karademir, S.E. Novel total antioxidant capacity index for dietary polyphenols and vitamins $\mathrm{C}$ and $\mathrm{E}$, using their cupric ion reducing capability in the presence of neocuproine: CUPRAC Method. J Agric Food Chem 2004. 52 (2004), 7970-7981.

21. Ghous, T.; Akhtar, K.; Nasim, F.U.H.; Choudhry, M.A. Screening of selected medicinal plants for urease inhibitory activity. Biol Med 2010. 2, 64-69.

22. Ellman, G.L.; Courtney, K.D.; Andress, V.; Featherstone, R.M. A new and rapid colorimetric determination of acetylcholinesterase activity. Biochem Pharmacol 1961. 7, 88-95.

23.Luís, Â.; Fernanda, D.; Duarte, A.P. Bioactive compounds, rp-hplc analysis of phenolics, andantioxidant activity of some portuguese shrub species extracts. Nat Prod Commun 2011. $6(12), 15-32$. 